\title{
FLOW CYTOMETRY BASED MICRONUCLEUS ASSAY FOR EVALUATION OF GENOTOXIC POTENTIAL OF 2-ACBs IN HEPATIC CELLS HepG2
}

\author{
Angélica B. Barbezan1*, Carla J. B. Santos, Luma R. Carvalho', Daniel P. Vieira1, \\ Glaucia M. M. Santelli², Anna L. C. H. Villavicêncio ${ }^{1}$ \\ ${ }^{1}$ Instituto de Pesquisas Energéticas e Nucleares, Universidade de São Paulo/SP \\ Author contact: abarbezan@ipen.br \\ ${ }^{2}$ Departamento de Biologia Celular e do Desenvolvimento do Instituto de Ciências Biomédicas, \\ Universidade de São Paulo/SP
}

\begin{abstract}
Food irradiation is approved for use in more than 60 countries for applications and purposes in a wide variety of foods, being an effective and safe method for preservation and long-term storage. 2Alkylcyclobutanones (2-ACBs) are the only known radiolytic products generated from foods that contain fatty acids (Triglycerides) when irradiated. The acids analyzed in this study are palmitic and stearic, which when irradiated form 2-Dodecylcyclobutanones (2-dDCB) and 2-Tetradecylcyclobutanone (2-tDCB). Part of the 2-ACBs ingested is excreted through feces and part is deposited in adipose tissues. In vitro studies so far have been only in colon cells. The work used a human hepatoma cell line (HepG2) since the accumulation of fat in this organ is quite common. Micronucleus test was selected to evaluate possible genotoxic effects of 2-dDCB and 2-tDCB compounds when exposed to high concentrations (447, 1422 and $2235 \mu \mathrm{M}$ ) for 4 and 24 hours. Tests were performed in quadriplicates using flow cytometric analysis. None detectable genotoxic damage was observed after 4 hours of exposure to the compounds, and cytotoxic effects were only significant at the highest concentration $(2235 \mu \mathrm{M})$ of 2-dDCB. After 24 hours of exposure, slight genotoxic damage was observed at all concentrations evaluated, and cytotoxic effects were only present when exposed to compound 2-tDCB. Although there is a genotoxic and cytotoxic effect in some of the situations tested, the two compounds predominantly induced proliferation reduction effects of this hepatic tumor cell line.
\end{abstract}




\section{INTRODUCTION}

\subsection{Food Irradiation}

There are three types of radiant energy for food irradiation: electron beams, X-rays and gamma rays. The first two types, do not use nuclear energy, but electricity as a source of energy. Gamma irradiation, an ancient method, is the only form of nuclear radiant energy. It uses radioactive sources, such as Cobalt 60 and Cesium 137. Neither form of radiant energy makes the food to become radioactive $[1,2]$.

Depending on the dose of irradiation absorbed, various effects can be achieved,resulting in reduced storage losses, longer shelf life and improved food safety, reducing the biological load of pathogenic microorganisms possibly present in food [1].

The beneficial effects of food irradiation have resulted in a number of practical advantages which include, in addition to versatility, the broad spectrum effective against bacteria, insects and other pests, its pervasiveness (foods are treated in their final packaging), and allow sterilization of solid and raw foods. Treatment does not involve chemical products and wastes, and food can be distributed immediately in the food supply chain after treatment [3].

\subsection{2-Alkylcyclobutanones}

2-Alkylcyclobutanones (2-ACBs) are the only radiolytic products formed from foods containing triglycerides (fatty acids) and are irradiated. 2-ACBs were first detected in foods irradiated by Letellier and Nawar in 1972. They found that when the triglycerides containing $\mathrm{C} 6, \mathrm{C} 8, \mathrm{C} 10, \mathrm{C} 12, \mathrm{C} 14, \mathrm{C} 16$ and $\mathrm{C} 18$ that were irradiated in the alkylcylcyclobutanone alkyl group 2 were then substituted and then the radiolytic products were formed.

2-ACBs are cyclic compounds formed by the loss of an oxygen electron in the carbonyl of a fatty acid or triglycerides, followed by a rearrangement process that produces ionization and induces the production of highly active free radicals. Therefore, palmitic, stearic, oleic and linoleic acids are the primary fatty acids present in foods which, when treated by the irradiation process, are transformed into 2-dDCB (2Dodecylcyclobutanone), 2-tDCB (2-Tetradecylcyclobutanone), 2 -tDeCB (2-tetradec-50enylcyclobutanone) and 2-tDdeCB (2-tetradec-5'8'-dienylcyclobutanone) respectively [4, 5].

The main concern with the consumption of irradiated food is the possible promotion of cancer. There are reports of toxicity from the preliminary evidence of the possible genotoxic effect of 2-ACBs [6]. Complete studies on the possible effects of 2-ACBs on irradiated foods as well as their mechanism of action to promote some tumor effect are urgently needed to address public health concerns. A thorough investigation of 2-ACBs 
effect on levels consumed by human and animal population models (in vitro and in vivo) of various types of cancer in different tissues is extremely important before proposing that irradiated foods may or may not promote colon cancer or other cancers [7].

A variety of tests for short-term toxicological studies have been used to evaluate the genotoxic and cytotoxic potential of food additives and chemicals formed by processing technologies [8].

\subsection{Genotoxicity test - Micronucleus test}

First described by Schimidt W. in 1975 the micronucleus test was performed on mammals by in vivo test. It has the property of detecting chromosomal changes during cell division, caused by mutagenic substances $[9,10]$.

The micronucleus consists of a round or oval-shaped cytoplasmic portion of chromatin that is located near the nucleus. Its formation results from a breakdown in the DNA molecule, days or weeks after the action of carcinogens when the cells of the basal layer are in division. They are constituted of chromatid fragments or, acentric or aberrant chromosomes, that were not included in the main nucleus after the conclusion of mitosis [11].

It is very important to emphasize that the test recommended by the guide OECD 487 In vitro Mammalian Cell Micronucleus Test, the cell count as well as micronucleus is performed by light microscopy, or fluorescence-based microscopy [12]. However, the search for automation of the MN assay is increasing in several research groups. The use of flow cytometry has been shown to be a facilitator during cell counting and micronucleus, due to the speed of the analyzes compared to the traditional method of slide analysis with the aid of an optical microscope [13]. Its use brings great advantages as questions speed and objectivity of analysis.

To test whether exposures to 2-ACB's can induce genotoxic stress, micronucleus test was carried out to evaluate possible genotoxic damage in the following concentrations: 447 , 1422 and $2235 \mu \mathrm{M}$ of 2-dDCB and 2-tDCB in different incubation times: 24 and 48 hours in hepatic cells of the HepG2 cell line.

\section{MATERIAL AND METHOD}

\subsection{Test substances 2-dDCB and 2-tDCB}


2-dDCB (CAS 35493-46-0) and 2-tDCB (CAS 35493-47 -1) were purchased from SigmaAldrich (USA). Proper dilutions were made in cell culture media and filter sterilized $(0.22 \mu \mathrm{m})$ prior to use. The final concentrations were: 447,1422 e $2235 \mu \mathrm{M}$.

\subsection{HepG2 Hepatic Cell Line}

Human hepatoma cells (HepG2, ATCC HB-8065) obtained from cell bank of Cell Biology and Tissue Dept. (Institute of Biomedical Sciences - Univ. of São Paulo / ICBUSP) were cultured in $25 \mathrm{~cm}^{2}$ bottles DMEM medium (Dulbecco's Modified Eagle Medium) (Vitrocell-Embriolife) supplemented with 10\% Fetal Bovine Serum (SFBGIBCO-BRL) and 1\% of Antibiotics (Penicillin, Streptomycin - GIBCO-BRL), incubated at $37^{\circ} \mathrm{C}$ in the presence of $5 \% \mathrm{CO} 2$ until approximately $70 \%$ confluence in monolayer, with replacement of the culture medium every 48 hours and subcultured after reaching near confluence (approximately 80 to $90 \%$ of the cell population).

\subsection{Micronucleus Assay}

HepG2 cells were prepared in 80,000 cells $/ \mathrm{mL}$ suspensions of culture medium and seeded in 96 wells in the density of 8000 cells/well in quadruplicates. After 48 hours, the culture medium from the wells was removed and received $100 \mu \mathrm{L}$ of fresh medium with the dilutions of 2-dDCB or 2-tDCB, or the positive and negative controls.

Two independent set of experiments were carried by 4 or 24 hours of incubation time with test substances or controls. After these periods, cells were with sterile PBS at $37^{\circ}$ $\mathrm{C}$, received freshy medium and put again in incubator for $24 \mathrm{~h}$.

Colchicine (Sigma Aldrich CAS 64-86-8)) was diluted in culture medium at a final concentration of $1.1 \mu \mathrm{g} / \mathrm{mL}$ performed a positive control. Negative genotoxicity control was represented by addition of a $\mathrm{NaCl} 0,9 \%$ solution in culture medium.

\subsection{2-Color Flow Cytometry for MN Quantification}

After 72 hours in culture, cells seeded in 96 well plates irradiated or treated with the described genotoxic agents or control (untreated) cultures were washed in PBS and received a solution of ethidium bromide monoazide dye (Thermo-Fisher Scientific, E1374) at a concentration of $8.5 \mu \mathrm{g} / \mathrm{ml}$ diluted in PBS supplemented with $2 \%$ fetal bovine serum. The culture plates were opened and exposed to a blue led light source (440$450 \mathrm{~nm}, 30 \mathrm{~W}$ ) source for 30 minutes for photoactivation of the compound, which was irreversibly associated only with the DNA of non-viable cells. This procedure aimed to efficiently label cells that should not be included in the counting of nuclei and micronuclei, in addition to providing some measure of cytotoxicity. After this step, the cells received PBS with $2 \%$ fetal bovine serum and centrifuged for removal of free dye. 
Two lysis steps were performed to release nuclei and micronuclei and to stain its DNA. The first step consisted in lysing the cells using a solution with sodium chloride $(0.854 \mathrm{mg}$ / $\mathrm{mL})$, sodium citrate $(1 \mathrm{mg} / \mathrm{mL})$ and IGEPAL $(0.3 \mu \mathrm{L} / \mathrm{mL})$, as well as $0.4 \mu \mathrm{M}$ SYTOX Green fluorescent dye (Thermo-Fisher Scientific, S7020). After lysis for 60 minutes (37 ${ }^{\circ} \mathrm{C}$ ), the plates were centrifuged and received the second lysis solution (sucrose $85.6 \mathrm{mg} /$ $\mathrm{mL}$, citric acid $15 \mathrm{mg} / \mathrm{mL}$ and SYTOX Green $0.4 \mu \mathrm{M}$ ). Second lysis solutions were supplemented with $5 \mu \mathrm{L} /$ well of fluorescent latex beads (AccuCheck Couting Beads, Molecular Probes). After 30 minutes at room temperature, the material was set ready for reading on the flow cytometer (Accuri C6, BD Biosciences).

Visual checking of events was performed using a fluorescence microscope (Nikon ECLIPSE TS 100) coupled to a Lumencor ${ }^{\circledR}$ Mira Light Engine (4-NII-FA), through a filter set with a 460-490nm and 500-560 excitation and emission spectra.

The analysis followed the methodology described in the literature [14]. Briefly, events marked with EMA were excluded from the total count. Events with SYTOX were evaluated according to their size (FSC) and fluorescence (FL1) for discrimination between nuclei and micronuclei. At least 20000 events gated on nuclei region were counted in each sample. Data was collected from two independent experiments in octuplicates as percentages of EMA-positive events and SYTOX-positive MN events and results were given as fold-changes comparing to control wells (non-irradiated, nontreated cells). Nuclei-to-bead ratios (NBP) score was used to find cell division ratios differences between groups. Gating strategy to analysis is depicted on Fig. 1.
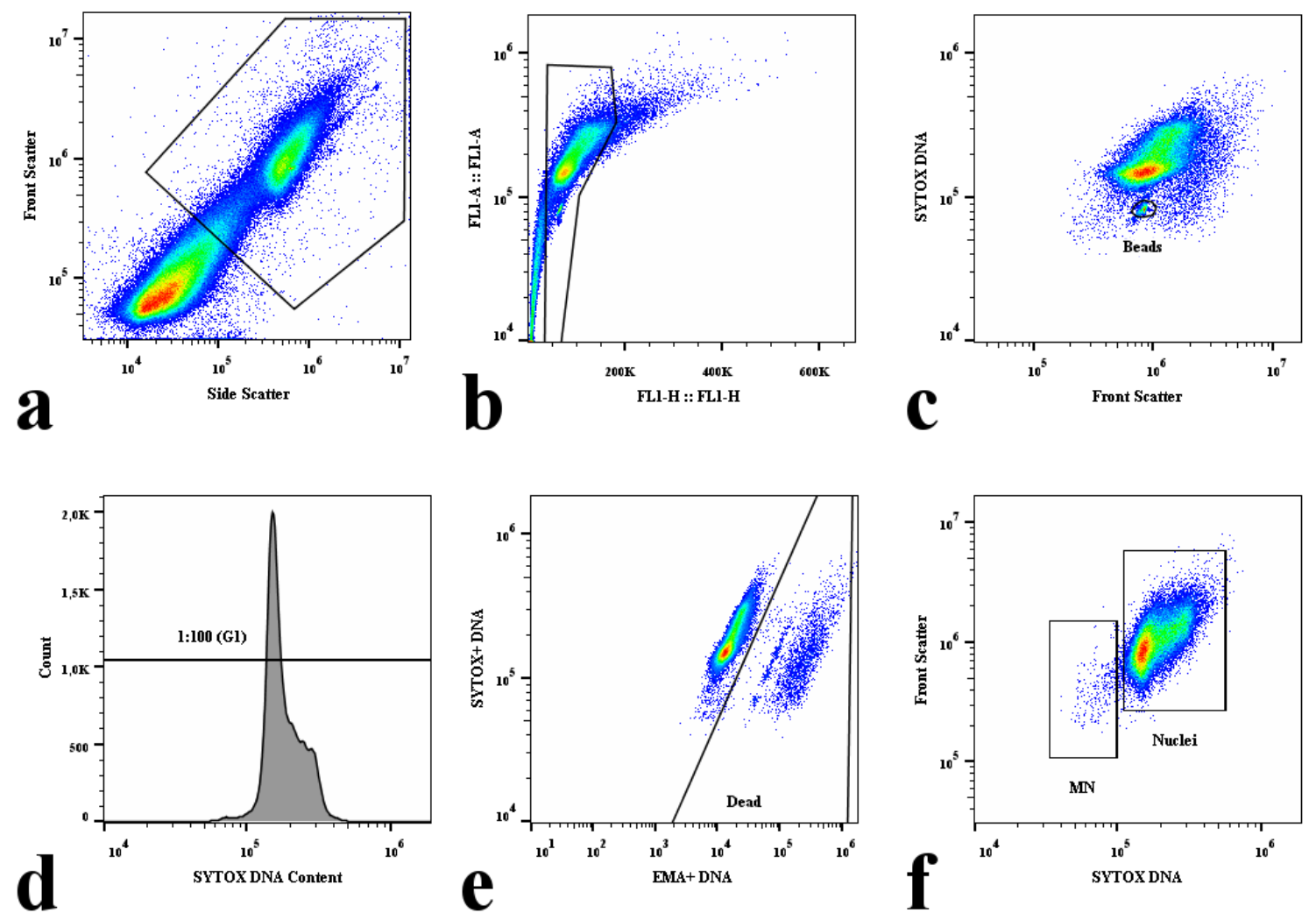
Figure 1: Gating strategy of this study. (a) Removal of cell debris; (b) Removal of doublets; (c) Latex beads region; (d) Minimal SYTOX fluorescence of 1/100 of G1 nucleus; (e) Dead $\left(\mathrm{EMA}^{+}\right)$cells; (f) Nucleus and micronucleus regions

Events labeled by SYTOX and EMA were associated with cell death and therefore provided a measure of cytotoxicity. Events labeled only by SYTOX, both nuclei and micronuclei, were evaluated in genotoxicity analysis. Percentages of micronucleus in relation to total SYTOX+ / EMA- events were used as a measure of genotoxicity. The SYTOX + / EMA- beads and nuclei counts provided the Nuclei-to-bead ratio, which is the measure of cell proliferation in this experiment.

\subsection{Statistical analysis}

The results were compared using ANOVA and Bonferroni post-tests.

\section{RESULTS}

HepG2 cultures were exposed to described concentrations of 2-dDCB and 2-tDCB or controls for 4 or 24 hours. Cultures obtained after incubation by 4 hours were analyzed for assessment of genotoxic damage (Fig 2), cell death (Fig 3) and possible changes in cell cycle rhythm (Fig 4).

Visual aspect of events generated by plasma membrane lysis are shown in Fig 5 (controls), Fig 6 (2-dDCB) and Fig 7 (2-tDCB).

No significant genotoxic damage was observed at the evaluated concentrations of 447 , 1422 and $2235 \mu \mathrm{M}$, although 2-dDCB $2235 \mu \mathrm{M}$ induced cell mortality at a significant extent (Fig 3). Only 2-tDCB $447 \mu \mathrm{M}$ did not reduce cell proliferation (Fig 4) 


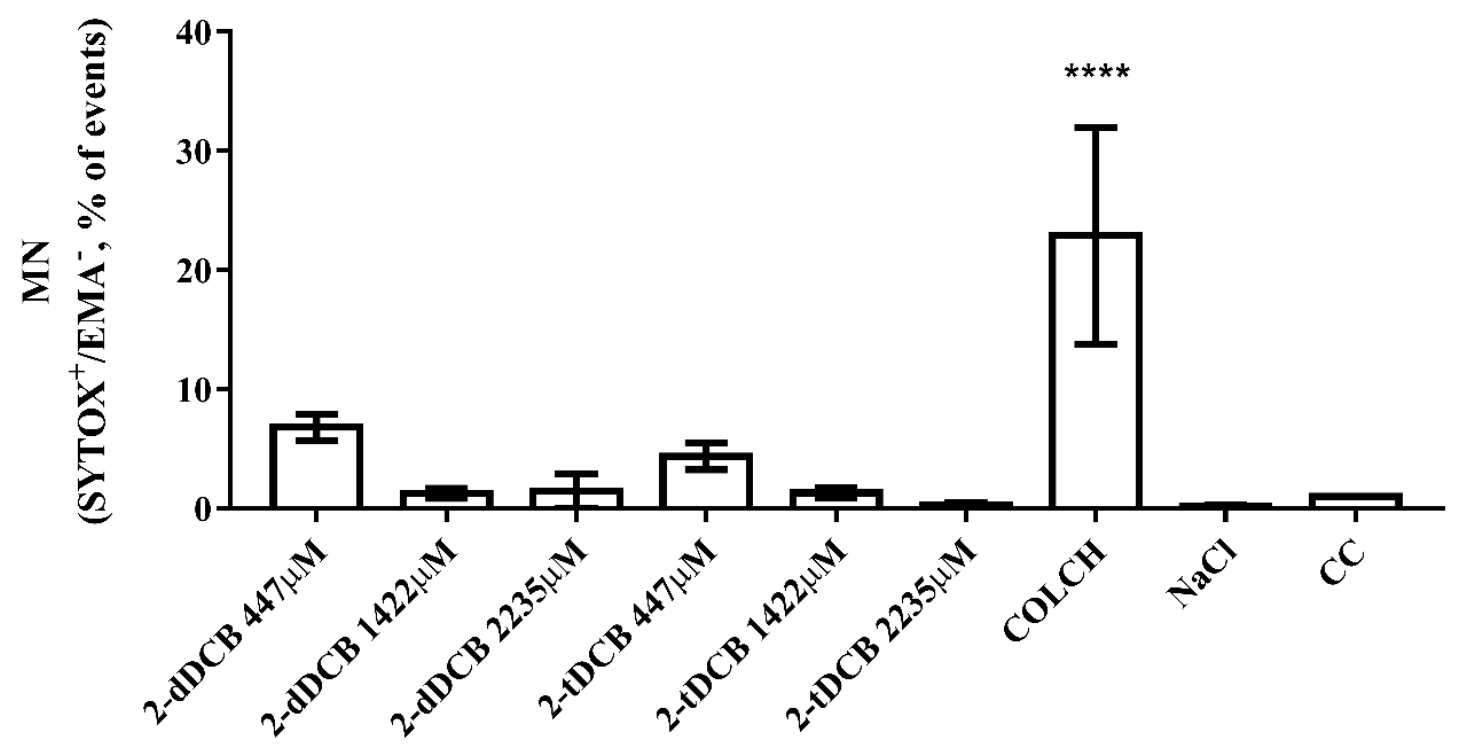

Figure 2 - MN cells formed after the cell line received treatment with the 2-dDCB and 2-tDCB compounds at the concentrations of 447, 1422 and $2235 \mu \mathrm{M}$. Colchicine, $\mathrm{NaCl}$ and $\mathrm{CC}$ (Cell Control) were used as controls (Values expressed in\%). (****): $\mathbf{p}<\mathbf{0 . 0 0 0 1}$.

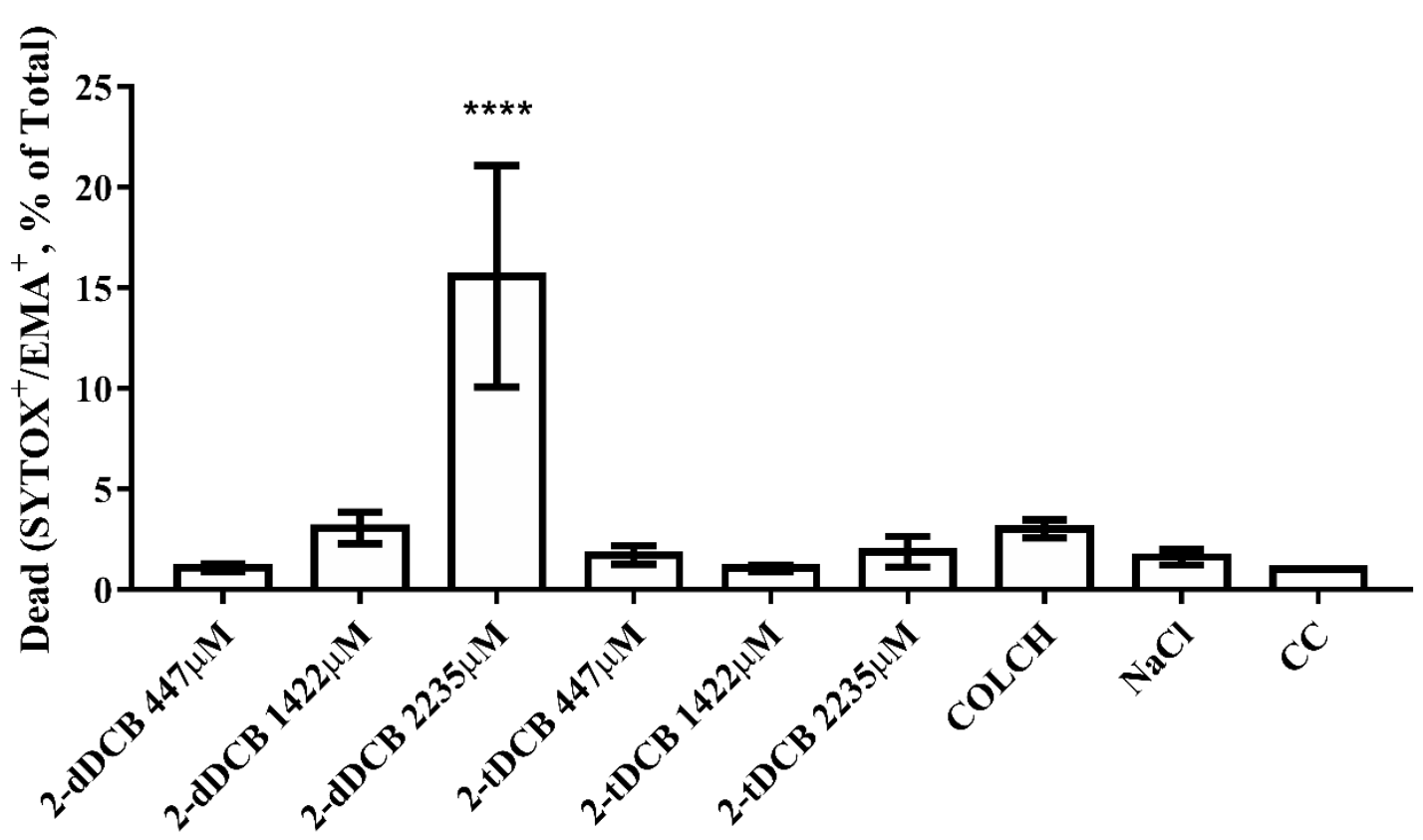

Figure 3 - \% of non-viable cells (death) after cell line received treatment with the 2-dDCB and 2-tDCB compounds at the concentrations of 447, 1422 and $2235 \mu M$ 
in the 4 hour period. $(* * * *): \mathbf{p}<0.0001$.

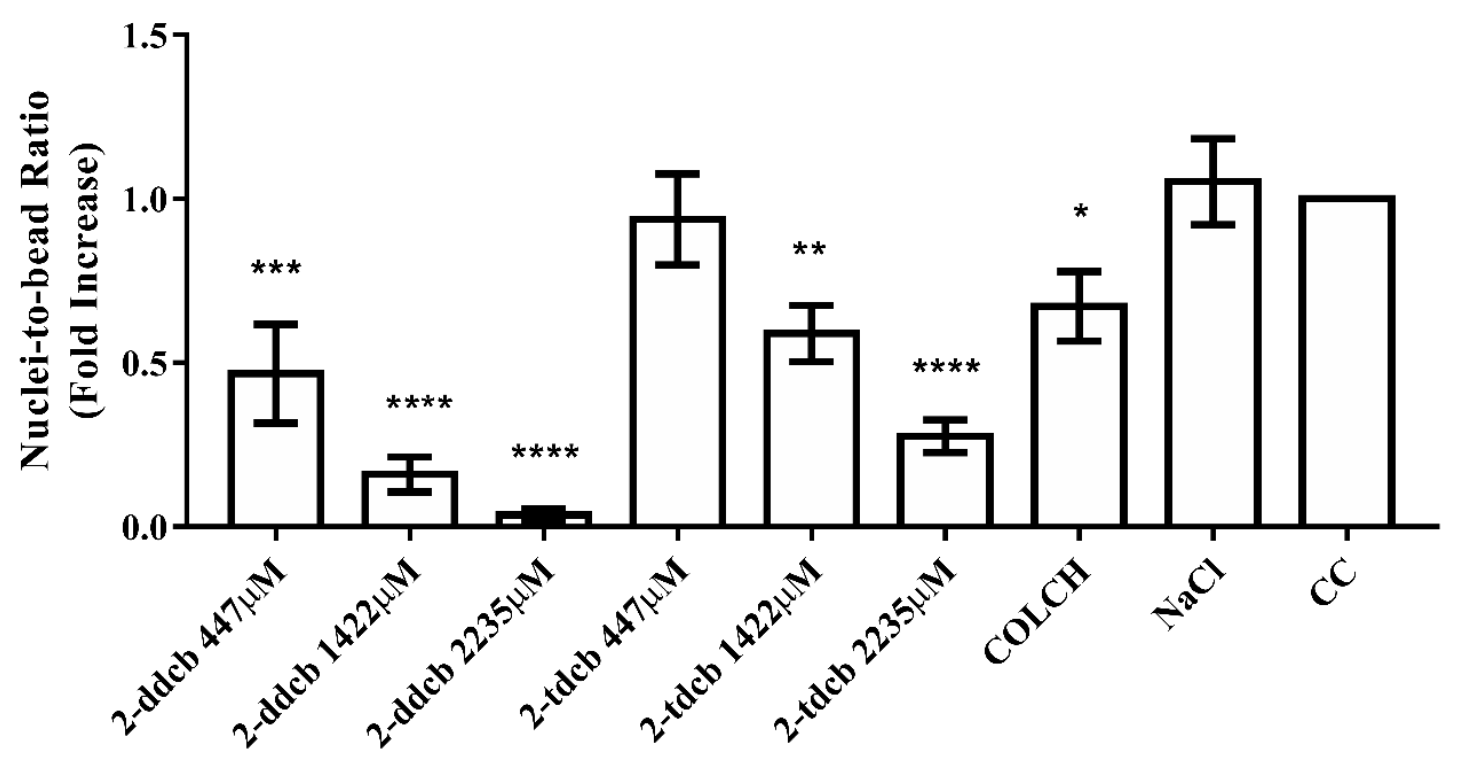

Figure 4 - Nuclei-to-bead ratio of HepG2 cells exposed 4 hours to 2-dDCB or 2tDCB $(447,1422,2235 \mu M) .(*):$ p $<0.05 .(* *): p<0.01 .(* * *): p<0.001 .(* * * *)$ : $\mathbf{p}<0.0001$.
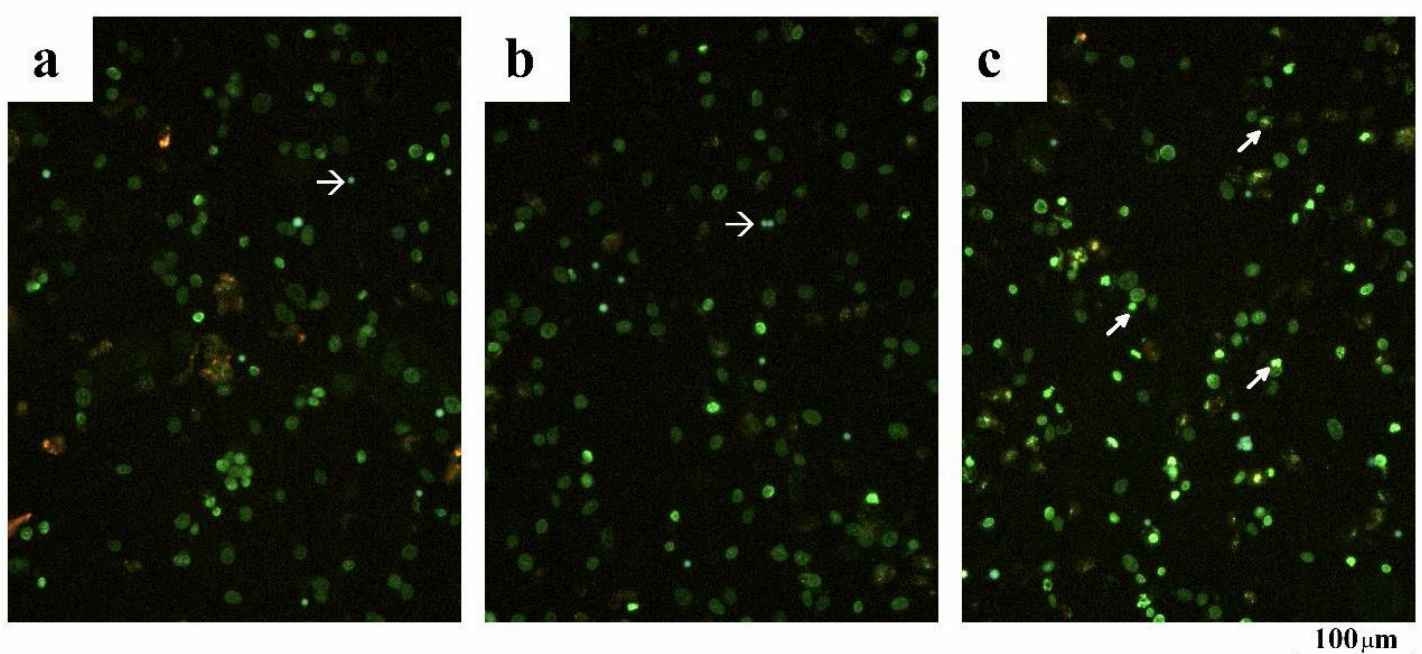

Figure 5 - Controls: (a) HepG2 line without receiving any treatment, (b) Cells treated with $\mathrm{NaCl}$ alone, (c) cells treated with Colchicine. Closed, small arrows Micronuclei. Open, large arrows - fluorescent latex beads. 

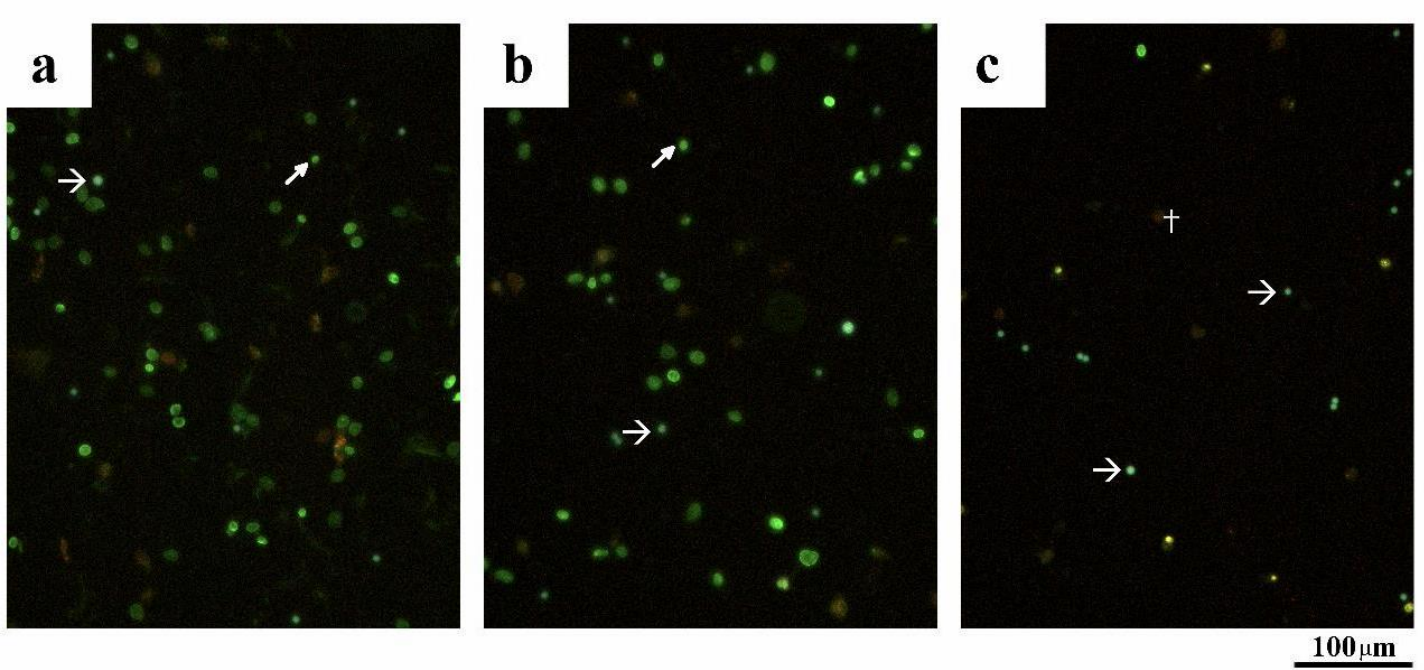

Figure 6 - HepG2 cell line treated at concentrations: (a) $447 \mu \mathrm{M}$, (b) $1422 \mu \mathrm{M}$ and (c) $2235 \mu \mathrm{M} 2$-dDCB, incubation period of 4 hours. (At the tip of the arrow micronucleus found). Closed, small arrows - Micronuclei. Open, large arrows fluorescent latex beads. Cross - Nuclei from dead cells.
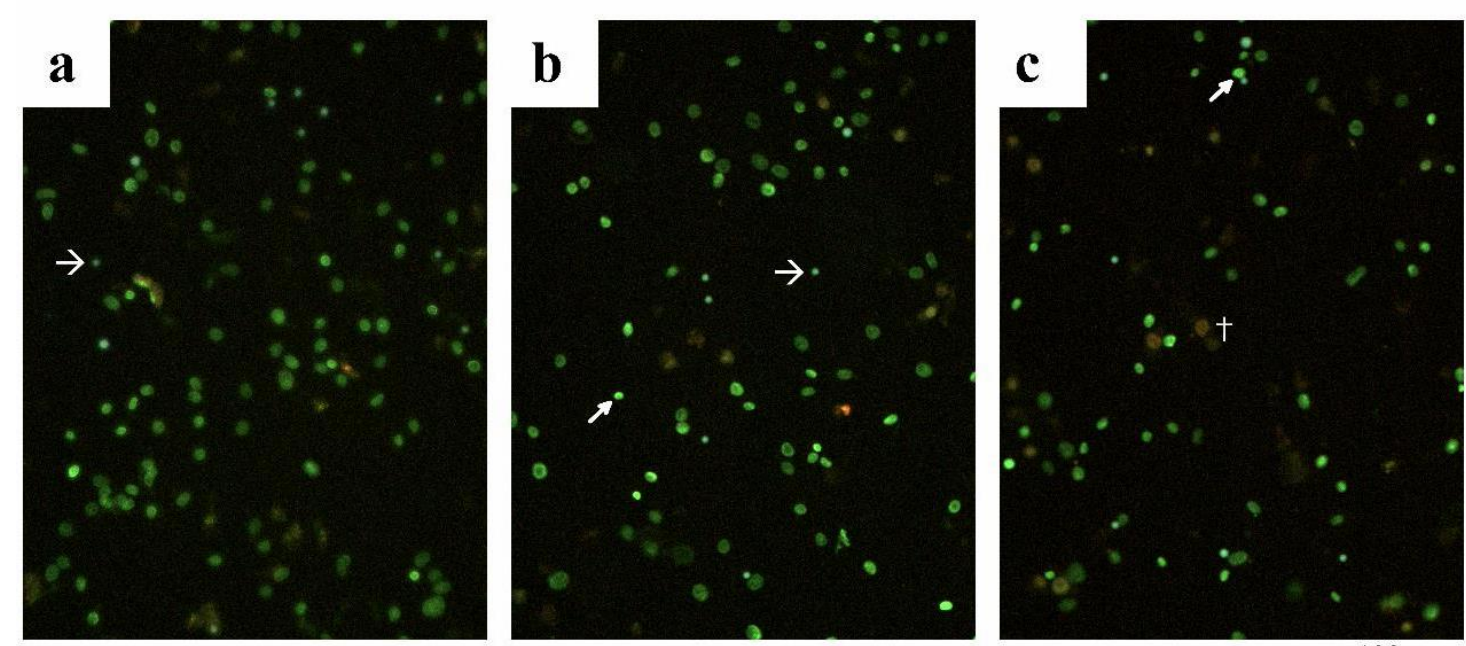

Figure7 - HepG2 cell line treated at concentrations: (a) $447 \mu \mathrm{M}$, (b) $1422 \mu \mathrm{M}$ and (c) $2235 \mu \mathrm{M}$ 2-tDCB, incubation period of 4 hours. Closed, small arrows Micronuclei. Open, large arrows - fluorescent latex beads. Cross - Nuclei from dead cells.

Results of MN induction (Fig. 8), cell death (Fig 9) and cell cycle (Fig 10) obtained from cultures incubated for 24 hours showed that 2-ACB's are not genotoxicity inductors, although exposures reduced cell proliferation in all concentrations of 2-dDCB and 2-tCB. Furthermore, 2-tDCB exposures increased cell death in all concentrations. Visual aspect of this set of experiments are shown in Figs. 11-13 


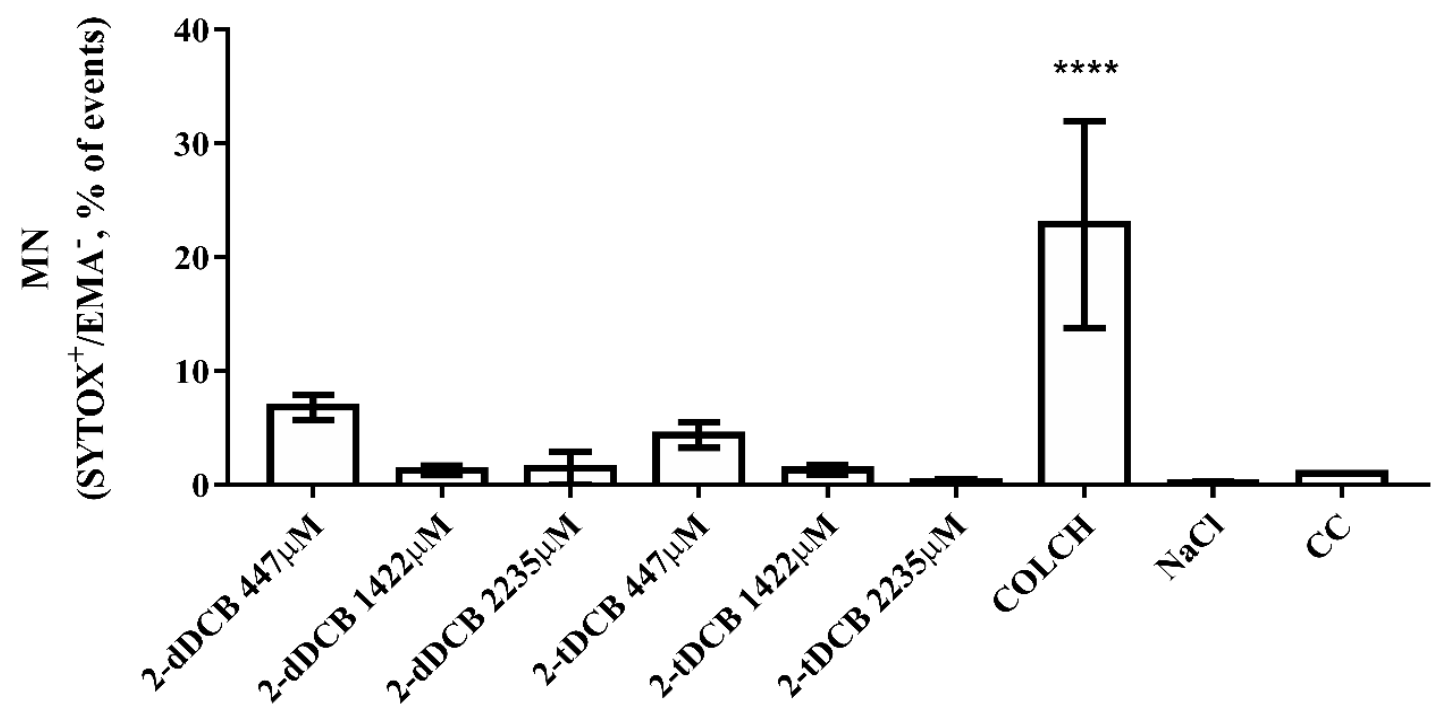

Figure 8 - MN cells formed after the cell line received treatment with the 2-dDCB and 2-tDCB compounds at the concentrations of 447, 1422 and $2235 \mu \mathrm{M}$. Colchicine, $\mathrm{NaCl}$ and $\mathrm{CC}$ (Cell Control) were used as controls (Values expressed in\%). (****): p $<0.0001$

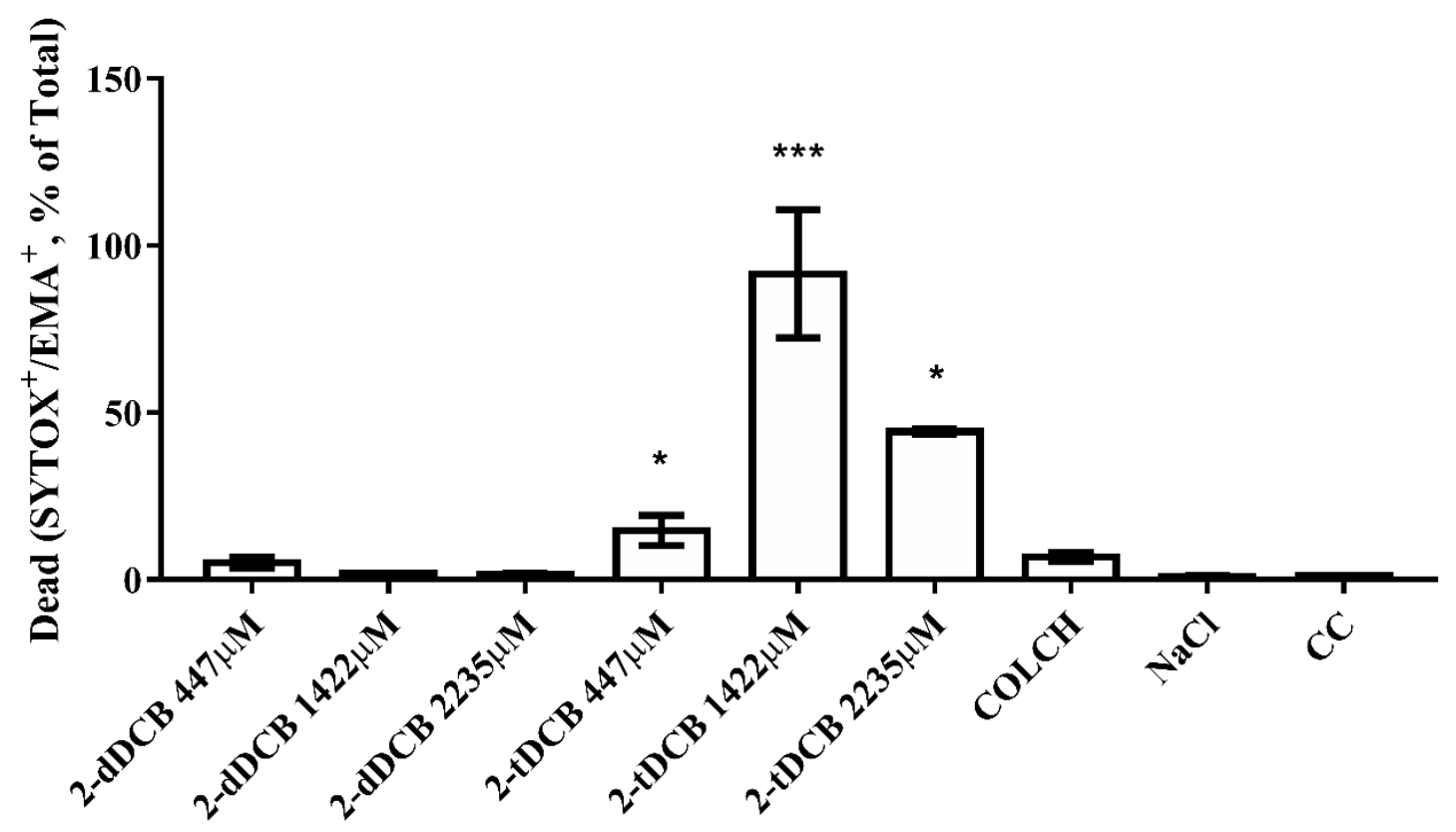

Figure 9 - Cells not viable after receiving treatment with the compounds (2-dDCB and tDCB for a 24 hour incubation period.) The concentration most expressing cell death was $1422 \mu \mathrm{M}$ (Values expressed in\%). 0.0001 


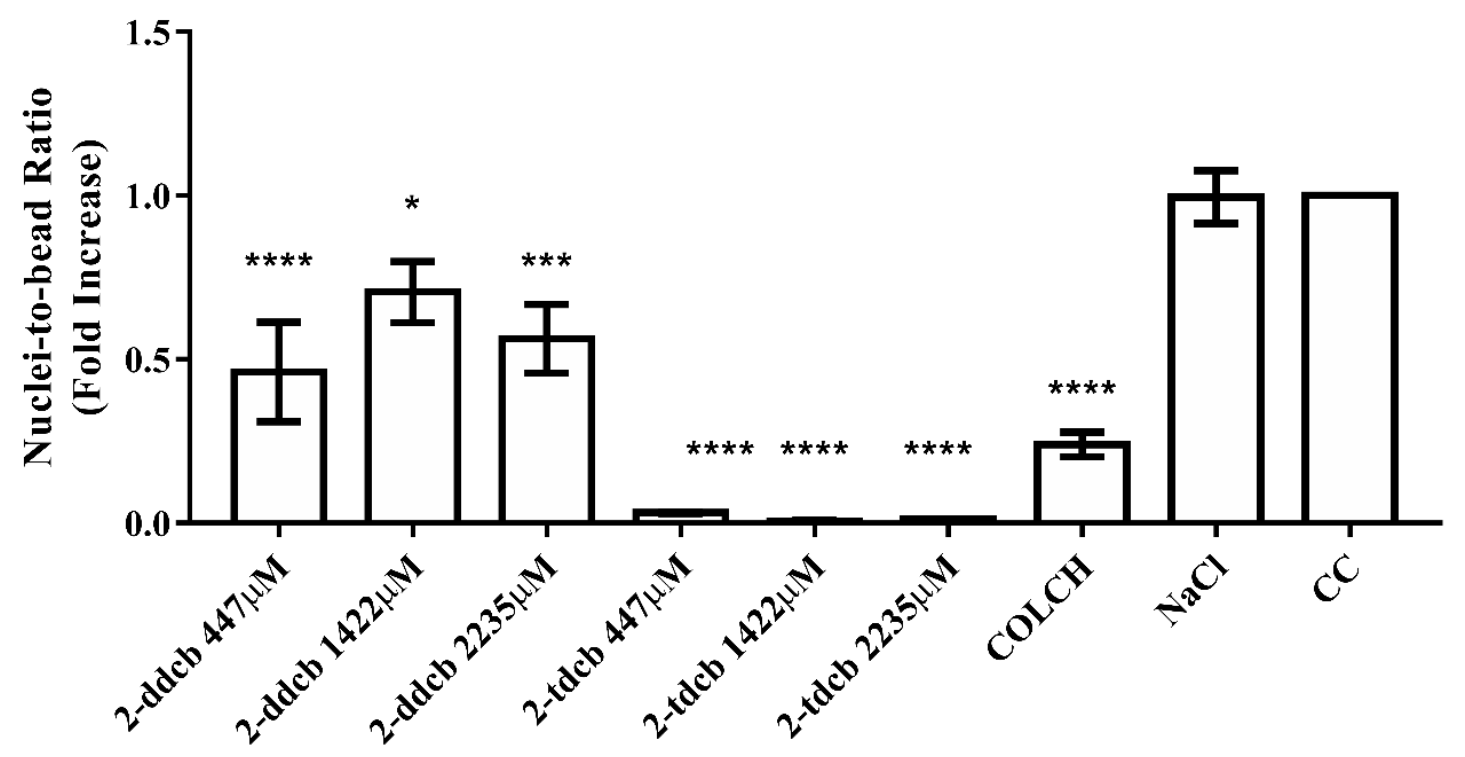

Figure 10 - Nuclei-to-bead ratio of HepG2 cells exposed 24 hours to 2-dDCB or 2tDCB (447, 1422, $2235 \mu \mathrm{M}) .(*): \mathbf{p}<0.05 .(* *): \mathbf{p}<0.01 .(* * *): \mathbf{p}<0.001 .(* * * *)$ : p<0.0001.
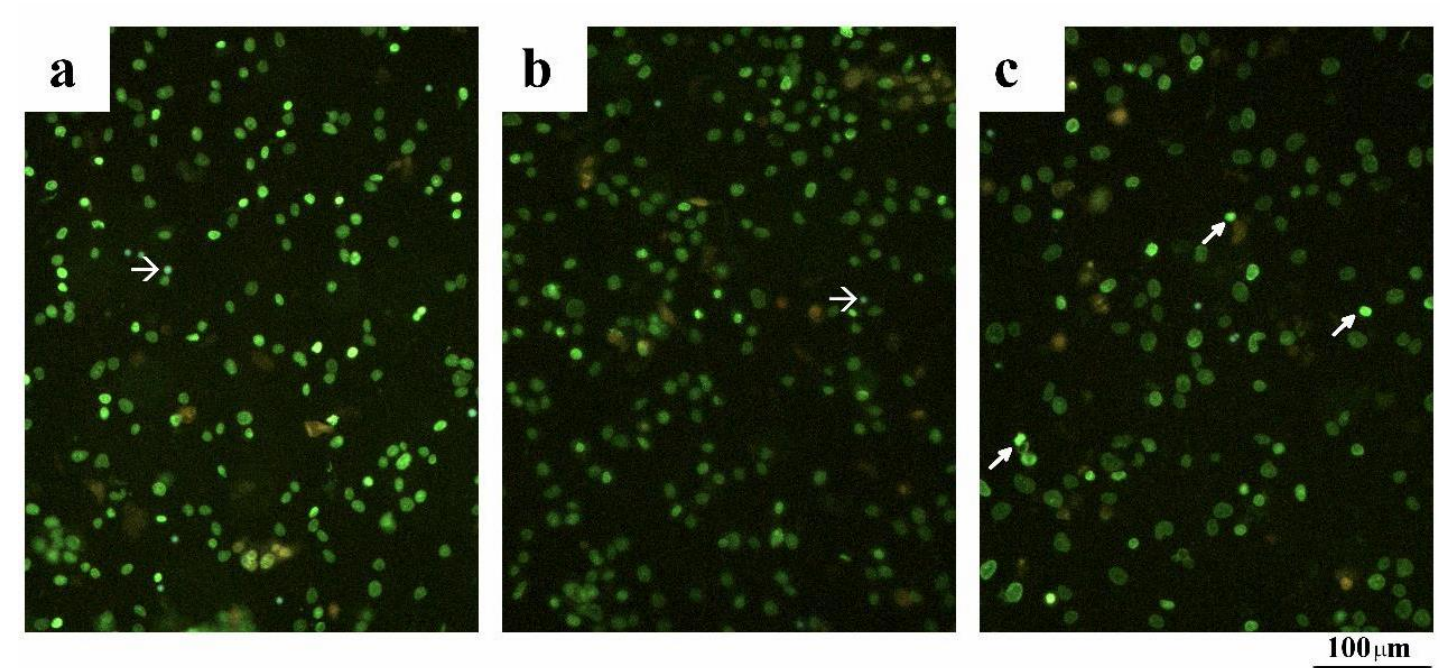

Figure 11 - Controls: (a) HepG2 line without receiving any treatment, (b) Cells treated with $\mathrm{NaCl}$ alone, (c) cells treated with Colchicine. (At the tip of the arrow micronucleus found) 

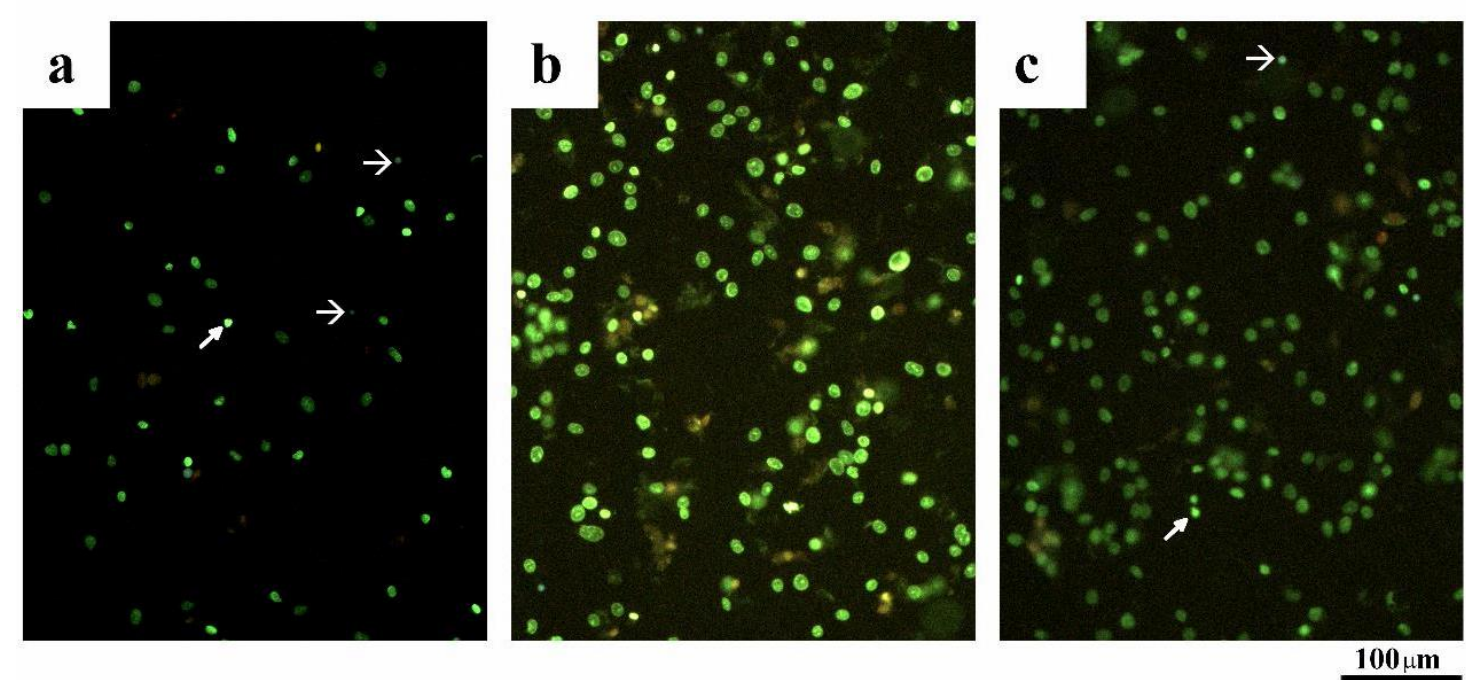

Figure 12 - HepG2 cell line treated at concentrations: (a) $447 \mu \mathrm{M}$, (b) $1422 \mu \mathrm{M}$ and (c) $2235 \mu \mathrm{M}$ 2-dDCB, incubation period of 24 hours. Closed, small arrows Micronuclei. Open, large arrows - fluorescent latex beads. Cross - Nuclei from dead cells.
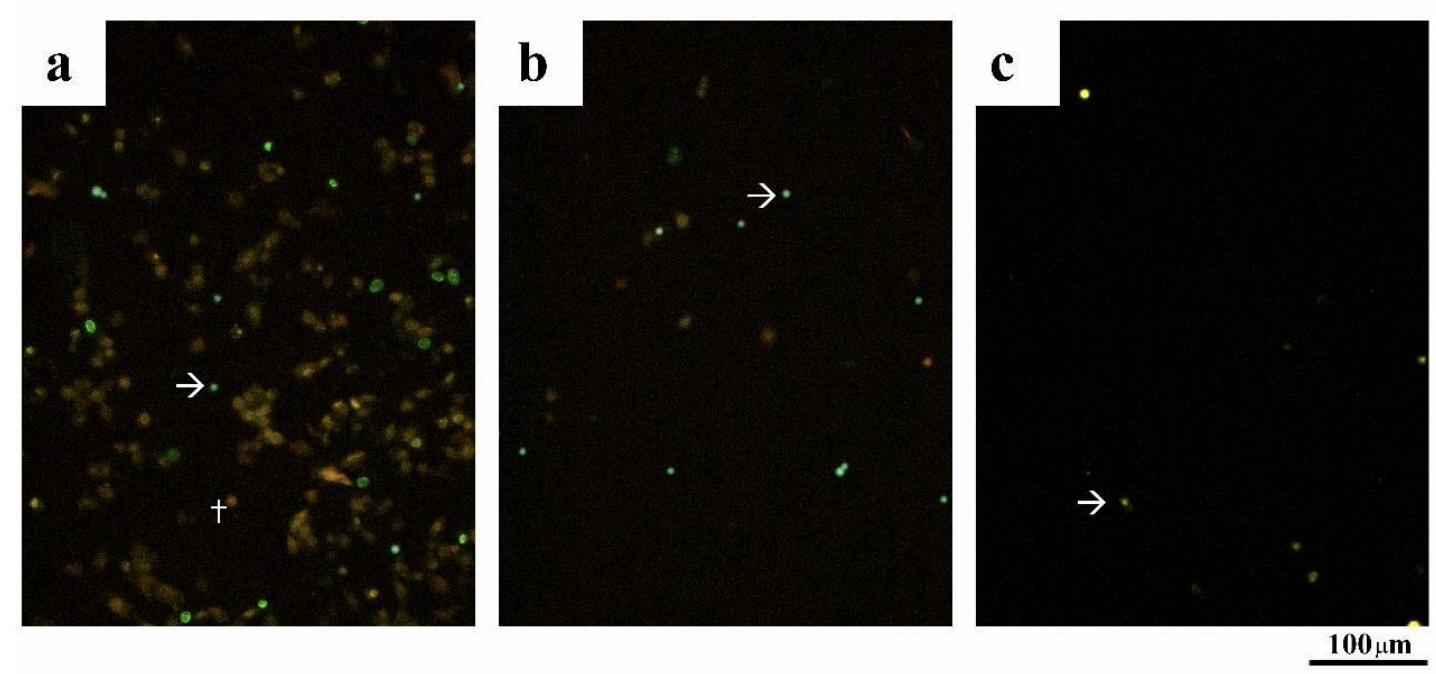

Figure 13 - HepG2 cell line treated at concentrations: (a) $447 \mu \mathrm{M}$, (b) $1422 \mu \mathrm{M}$ and (c) $2235 \mu \mathrm{M}$ 2-tDCB, incubation period of 24 hours. Open, large arrows - fluorescent latex beads. Cross - Nuclei from dead cells.

\section{DISCUSSION AND CONCLUSION}

Few studies have been performed regarding the evaluation of the possible genotoxic effects of 2-ACBs. As reported in the literature, most of these evaluations were done through the comet test and only one group led by Yamakage et al. 2014 used the MN assay for this purpose. The present study focused on in vitro effects rather than the in vivo like the last cited authors 
Since there is no research concerning the genotoxicity of 2-ACBs with this cell line, relatively high doses were selected when compared to studies already performedin other techniques such as the cell viability test.

Micronucleus tests results showed none detectable genotoxic damage was observed after 4 hours of exposure to the compounds, and cytotoxic effects were only significant at the highest concentration $(2235 \mu \mathrm{M})$ of 2 -dDCB.

After 24 hours of exposure, the experiments also could not detect genotoxic damage at all concentrations evaluated, and cytotoxic effects were only present when exposed to compound 2-tDCB.

In this way we can conclude that although cytotoxic effect in some of the situations tested, especially when dealing with exposure to relatively high doses of 2-ACBs, doses that do not apply to real human consumption, since we do not feed exclusively with irradiated foods, the two compounds induced predominantly proliferation-reducing effects of this hepatic tumor line. However, if for example in the consumption of an animal that feeds on irradiated exclusive ration, perhaps this condition could be a problem, in this way, more studies evaluating the effects of these compounds in other cell lines is of great importance, so that doses absolutely safe for both human and animal health can be determined.

Finally, it is important to note that the irradiation of certain foods and food ingredients is regulated by the EU (European Community) which lists the foodstuffs that can be treated with radiation, which ones cannot be treated, as well as the maximum doses of radiation that they can receive (Average absorbed radiation dose of $10 \mathrm{kGy}$ ). Proper labeling of food products and ingredients is required at EU, FAO / OMS Codex Alimentarius levels and use 2-ACB detection methods as indicators to verify whether there has actually been compliance with the legislation [16].

In Brazil, despite the food irradiation process being authorized, we still do not have a regulatory body that controls similarly to what is practiced in Europe and the United States. This lack of surveillance allows the labeling to not follow any standard radiation information and dosage. It is a field that still lacks enormous maturation.

Hence, studies like this have been performed nationally in order to standardize and adequately inform the use of radiation in the foods produced and distributed.

\section{ACKNOWLEDGMENTS}

Special thanks to CNPq for their financial support. 


\section{REFERENCES}

1. FARKAS, J., EHLERMANN, D. A. E., \& FARKAS, C. M. "Food Technologies: Food Irradiation. Reference Module in Food Science" - Encyclopedia Food Safety, v. 3, pp.178-186 (2014).

2. IAEA International Atomic Energy Agency (2017). "Gamma Irradiators for Radiation Processing", http://wwwnaweb.iaea.org/napc/iachem/Brochgammairradd.pdf

3. ROBERTS, P. B. "Food irradiation is safe: Half a century of studies", Radiation Physics and Chemistry. v. 105, pp. 78-82 (2014).

4. GADGIL, P., HACHMEISTER, K., SMITH, J. S., \& KROPF, D. H. “2Alkylcyclobutanones as Irradiation Dose Indicators in Irradiated Ground Beef Patties". Journal Agricultural and Food Chemistry, v. 50, pp. 5746-5750 (2002).

5. SONG, B. S., CHOI, S. J., JIN, Y. B., PARK, J. H., KIM, J. K., BYUN, E. B., KIM, J. H., ..., MARCHIONI, E. "A critical review on toxicological safety of 2alkylcyclobutanones". Radiation Physics and Chemistry. v. 103, pp. 188-193 (2014).

6. DELINCEÉ, H., \& POOL-ZOBEL, B.L. "Genotoxic properties of 2dodecylcylobutanone, a compound formed on irradiation of food containing fat." Radiation Physical and Chemistry, v. 52, pp. 39-42 (1998).

7. CHINTHALAPALLY, V. R. "Do Irradiated Foods Cause or Promote Colon Cancer?" Nutrition and Cancer, v. 46, pp. 107-109 (2003).

8. TICE, R. R., E. AGURELL, D. ANDERSON, B. BURLINSON, A. HARTMANN, H. KOBAYASHI, Y. MIYAMAE, ..., Y. F. SASAKI. "Single cell gel/comet assay: guidelines for in vitro and in vivo genetic toxicology testing". Environmental and Molecular Mutagenesis. v. 35, pp. 206-221 (2000).

9. FLORES, M.; YAMAGUCHI, M.U. "Teste de micronúcleo: uma triagem para avaliação genotóxica", Revista Saúde e Pesquisa, v.1, n.3, pp. 337-340, (2008).

10. HAWLEY, T. S.; HAWLEY, R. G. Flow cytometry protocols. 2. ed. pp. 434. Humana Press Inc., Totowa, New Jersey (2004).

11. SETÚBAL, A.M.G.; REIS, S. R. A.; ROBINSON, W. M.; BORGES-OSÓRIO, M. R. "Micronúcleo: um importante marcador biológico intermediário na prevenção do câncer bucal." Revista Odonto Ciência- Faculdade de Odontologia/PUCRS, v.20, n.28, (2005).

12. I. Z. OCAMPO, P.Q.S. PASSOS, L.R. DE CARVALHO, C.A.L. DA CRUZ, N.M. ESTEVES-PEDRO, F.M. DA SILVA, O.Z. HIGA, L.A. DIAS, K. OKAZAKI, D.P. VIEIRA, "In vitro cytotoxic and genotoxic evaluation of peptides used in nuclear medicine (DOTATATE and Ubiquicidin (29-41)) in 
CHO-K1 cells," Cytotechnology. 68, pp. 2301-2310 (2016).

13. ESTEVES-PEDRO, N. M. "Avaliação in vitro da toxicidade de óleos essenciais da flora Latino-americana candidatos ao uso em cosméticos. 2013". Dissertação (Mestrado) - Faculdade de Ciências Farmacêuticas da Universidade de SãoPaulo - pp. 42-47, http://www.teses.usp.br/teses/disponiveis/9/9139/tde-24092015120519/pt-br.php (2016).

14. BRYCE, S., SHI, J., NICOLETTE, J., DIEHL, M., SONDERS, P., AVLASEVICH, S., RAJA, S., BEMIS, J. C., DERTINGER, S. D. High content flow cytometric micronucleus scoring methods is applicable to attachment cell lines. Environ Mol Mutagen. v. 51, pp 260-266. (2010).

15. YAMAKAGE, K.; SUI, H.; OHTA, R.; TYOIZUMI, T.; KAWAKAMI, K.; MATSUMOTO, H.; TAKAHASHI, T.; SASAKI, K.; IKEZUMI, M.; NEGISHI, S.; IZUMI, K.; TODORIKI, S.; TAKASHI, K.; FURUTA, M. "Genotoxic potencial and in vitro tumour-promoting potential of 2-dodecylcyclobutanone and 2-tetradecylcyclobutanone, two radiolytic products of fatty acids". Mutation Research, v. 770, pp. 94-104, (2014).

16. BREIDBACH, A.; ULBERTH, F. "Comparative evaluation of methods for the detection of 2-alkylcyclobutanones as indicators for irradiation treatment of cashew nuts and nutmeg". Food Chemistry, v. 201, pp. 52-58 (2016). 